\title{
Sindicalismo da agricultura familiar e agroecologia no Alto Uruguai do RS*
}

\section{Family Farm Syndicalism and Agroecology in Alto Uruguai-RS}

\author{
Everton Lazzaretti PICOLOTTO**
}

\begin{abstract}
RESUMO
As preocupações ambientais têm influenciado os projetos políticos das organizações de agricultores familiares. O objetivo deste artigo é analisar como estas preocupações foram assimiladas pela Federação dos Trabalhadores na Agricultura Familiar da Região Sul (FETRAF-Sul) na região do Alto Uruguai do Rio Grande do Sul, principalmente na definição da pauta da agroecologia. Com base na consulta de documentos produzidos pelas organizações sindicais e suas assessorias, jornais e entrevistas com lideranças de agricultores, fez-se uma leitura sobre o processo de construção desta pauta no sindicalismo. Optou-se por fazer um estudo do município de Constantina-RS, onde são desenvolvidas experiências nessa área desde a década de 1980, para avaliar como as questões ambientais são internalizadas pelo sindicalismo em diferentes momentos.
\end{abstract}

Palavras-chave: agricultura familiar; agroecologia; FETRAF-Sul; Constantina.

\begin{abstract}
Environmental concerns have influenced the political projects of family farmers' organizations. The present paper aims to examine how these concerns were assimilated by the Federação dos Trabalhadores na Agricultura Familiar da região Sul (FETRAF-Sul) in the Alto Uruguai in Rio Grande do Sul, mainly in setting the agenda of agroecology. A review about the process of building this agenda in the trade unionism was based on the consultation of documents produced by trade unions and their press offices, newspapers and interviews with farmers' leaders. We decided to do a study about the town of Constantina-RS, where experiments have been carried out since the 1980s to assess how environmental issues have been internalized by unions in different periods.
\end{abstract}

Key-words: family farming; agroecology; FETRAF-Sul; Constantina.

\footnotetext{
" Sou grato aos valiosos comentários e sugestões que recebi na elaboração deste texto de Leonilde Medeiros, Vivien Diesel e Sergio Barcellos. Os possíveis erros e omissões remanescentes são de inteira responsabilidade do autor.

"* Doutor em Ciências Sociais em Desenvolvimento, Agricultura e Sociedade (CPDA), Universidade Federal Rural do Rio de Janeiro. Pós-Doutorado no Programa de Pós-Graduação em Sociologia da Universidade Federal do Paraná. Bolsista do CNPq. E-mail: picolottoae@yahoo.com.br
} 


\section{Introdução}

As preocupações ambientais do período contemporâneo têm influenciado organizações de representação de agricultores familiares a incluírem em seus projetos a perspectiva de apoio a formas e técnicas de produção causadoras de menores impactos ambientais, resgate de práticas de produção e de conhecimentos tradicionais, diversificação produtiva, práticas de agricultura sob preceitos agroecológicos, entre outras. A Federação dos Trabalhadores na Agricultura Familiar da região Sul (FETRAF-Sul), herdeira do sindicalismo rural da Central Única dos Trabalhadores (CUT), é um dos atores que, desde a sua origem, na década de 1980, tem procurado incluir em seu projeto político estas preocupações, ao passo que também tem estimulado e orientado ações práticas desse formato de agricultura entre os agricultores de sua base social.

Para promover novas práticas produtivas, tem sido importante a assessoria de organizações não governamentais (ONGs) que vêm construindo críticas aos efeitos perversos do processo de modernização da agricultura promovido no Brasil desde a década de 1960. A construção da pauta ecológica parte de um diagnóstico sobre as consequências negativas da modernização sob vários ângulos: as ambientais, com a destruição de recursos naturais, a erosão de solos, a contaminação de águas etc.; as socioeconômicas, com o êxodo rural, o empobrecimento e a exclusão dos pequenos agricultores do processo produtivo; e as culturais, com a perda dos conhecimentos tradicionais, do saber fazer e da etnobiodiversidade (DIEGUES, 2000). Da constatação dos efeitos negativos da modernização surgiram propostas de recuperar formas de produzir e de relação com a natureza do passado dos agricultores, buscando nelas embasamentos para constituir uma nova forma de produzir mais harmônica com a natureza.

Essa tentativa de resgate de técnicas de produção e formas de relação com a natureza do passado foi buscada, na região Sul, em especial nas práticas de um grupo específico de agricultores, os chamados colonos. Os colonos são entendidos como os descendentes de imigrantes europeus (alemães, italianos, poloneses, entre outros) que formaram colonias a partir de meados do século XIX e início do XX nas regiões de matas não apropriadas pelas grandes explora- ções. Nessas regiões, desenvolveu-se a pequena propriedade e um formato de exploração agropecuária diversificada, dedicada à subsistência familiar e ao comércio de alguns produtos agropecuários (ROCHE, 1969).

Com o processo de modernização da agricultura promovido pelo Estado nas décadas de 1960-70, os colonos foram incentivados a abandonar as formas tradicionais de produção, a adotar novas técnicas, consideradas mais modernas e eficientes, e acabaram se especializando na produção de poucas culturas e criações (como soja, trigo, uva, suínos, frangos, entre outras). Com a crise econômica do final da década de 1970 e início da de 1980, que atingiu fortemente a agricultura, muitos destes colonos que haviam seguido as orientações do Estado (mesmo que parcialmente) enfrentaram grandes dificuldades para se manter na atividade e muitos foram obrigados a migrar para as cidades ou a entrarem na luta por terra (BRUM, 1988; SCHMITT, 2001).

Foi neste contexto de desgaste do modelo de produção agrícola considerado moderno, de construção de oposição às grandes obras realizadas em nome do desenvolvimento nacional (barragens, estradas etc.), de crise do regime militar, do processo de abertura política e redemocratização do país consolidado com a Constituição de 1988 e de realização da II Conferência Mundial sobre Meio Ambiente e Desenvolvimento no Brasil (Eco-92) em 1992, que foram propiciadas as "oportunidades políticas" (TARROW, 2009) para se constituir no país diversos novos atores questionadores da situação vigente. Dentre eles, o movimento ambientalista e a emergência da pauta ambiental (ALONSO; COSTA; MACIEL, 2007).

Acompanhando estes processos mais amplos e visando gerar respostas às necessidades dos pequenos agricultores, surgiram iniciativas de diversificação da produção, tecnologias alternativas, experiências de agricultura de base ecológica, uso de sementes e insumos próprios etc. Surgiam como uma forma de reação às consequências negativas de modernização da agricultura e como forma de encontrar novos caminhos para os pequenos agricultores. Algumas formas de desenvolver práticas agrícolas de maneiras mais autônomas e harmoniosas com a natureza puderam ser buscadas nas suas experiências do passado, do período anterior à modernização da agricultura. Aparentemente, a partir de uma síntese entre o resgate de práticas antigas, novas

\footnotetext{
${ }^{1}$ Para Tarrow (2009, p. 99), as oportunidades políticas aparecem nos momentos em que sujeitos ou grupos sociais "recebem recursos externos para escapar da submissão" a que são submetidos e nas ocasiões em que se sentem "ameaçados por custos que não podem arcar ou que ofendem seu senso de justiça". Mas também, as oportunidades políticas "fornecem informações cruciais para a formação dos movimentos quando revelam aliados e expõem a fraqueza do inimigo." (TARROW, 2009, p. 100).
} 
preocupações com o ambiente e conhecimentos técnico-científicos, foram formadas as bases do que se chamou de agricultura alternativa ou tecnologias alternativas na década de 1980 e vêm sendo associadas no período mais recente à agricultura ecológica (também chamada pelas organizações de agricultores de agricultura orgânica ou agroecológica ${ }^{2}$.

Nessa forma de entender, as experiências de tecnologias alternativas e de agricultura ecológica dos agricultores no Sul do Brasil, na medida em que foram buscar formas de produzir do passado dos colonos e são pensadas a partir das dificuldades enfrentadas no período contemporâneo, podem ser lidas como formas de reinterpretar ou dar novos sentidos às formas tradicionais de produzir do grupo social, atualizando-as positivamente. Ao resgatar práticas do passado, ressignificadas com questões do tempo presente (preocupações ambientais), os agricultores buscaram alcançar um espaço na sociedade atual para os pequenos agricultores (ou agricultores familiares como passaram a ser chamados a partir dos anos 1990) e pensar, a partir de sua "experiência" enquanto grupo social (THOMPSON, $1981)^{3}$, um novo modelo de agricultura com menores impactos no ambiente.

Da confluência entre a experiência social e produtiva do grupo e as preocupações ambientais contemporâneas constituíram-se articulações entre organizações de representação (como a FETRAF/CUT), setores da Igreja Católica e Luterana e ONGs que buscavam formas de reinserir os colonos na sociedade nacional ao mesmo tempo em que se preocupavam com as questões ambientais. Como a FETRAF é herdeira destes processos, nos seus documentos a agricultura familiar é apresentada como o setor social que pode constituir uma relação mais harmoniosa entre homem e natureza, produzir alimentos diversificados e com qualidade para o povo brasileiro e conjugar as intenções de desenvolvimento agrícola com o respeito à natureza e às culturas locais (FETRAF, 2002; 2007; 2010). Para a FETRAF, o agricultor familiar passa a ser o personagem que pode consolidar um novo modelo de desenvolvimento para a agropecuária brasileira, onde as preocupações com inclusão social, desenvolvimento agrícola e preservação das culturas locais e do ambiente constituem eixos centrais.

Este artigo visa refletir sobre como a pauta ambiental foi internalizada pelo sindicalismo da FETRAF no Rio Grande do Sul, principalmente por meio da definição da pauta da construção da agroecologia. Para se analisar quais são os efeitos práticos desta pauta entre as bases do sindicalismo da FETRAF, escolheu-se analisar o caso do município de Constantina, um dos municípios do Alto Uruguai ${ }^{4}$ gaúcho historicamente vinculado ao sindicalismo rural da CUT e onde são desenvolvidas experiências nessa área desde a década de 1980. Na realização dos investimentos de pesquisa que deram base para este artigo, fez-se uso de consulta a documentos produzidos pelas organizações de agricultores e suas assessorias, jornais de circulação local e estadual que publicaram ações das organizações, entrevistas com lideranças de agricultores que foram realizadas originalmente para construção da dissertação de mestrado do autor (PICOLOTTO, 2006) e da tese de doutorado (PICOLOTTO, 2011), participação em eventos da Federação, além de consulta à bibliografia já existente sobre o tema.

\section{Crítica à modernização da agricultura, formação de uma rede agroambientalista e entrada da pauta ambiental no sindicalismo}

Na década de 1970, ocorreram profundas transformações no meio rural brasileiro, conduzidas centralmente pela

\footnotetext{
${ }^{2}$ Nesse texto não se tem objetivo de entrar na discussão sobre as diferenças conceituais entre os termos tecnologias alternativas, agricultura orgânica, agricultura ecológica e agroecologia. Ressalta-se apenas que enquanto a agroecologia, sob o ponto de vista acadêmico, deve ser entendida como um enfoque científico destinado a apoiar a transição dos atuais modelos de desenvolvimento rural e de agricultura convencionais para estilos de desenvolvimento rural e de agricultura sustentáveis (SEVILLA GUZMÁN, 2000; CAPORAL; COSTABEBER, 2000), para as organizações de agricultores os sentidos atribuídos ao termo agroecologia ou agricultura ecológica (usados em sentidos semelhantes) normalmente são mais amplos e aplicados às suas próprias experiências e práticas de agricultura que rompem em alguma medida com os modelos convencionais (BARCELLOS, 2009; PICCIN, 2007). Durante o trabalho, chama-se atenção para os usos que as organizações de agricultores fazem do termo agroecologia e outros que usam em sentidos próximos.

${ }^{3}$ Para Thompson (1981, p. 188-189) a "experiência" de uma classe ou grupo social é formada pelos "sistemas densos, complexos e elaborados pelos quais a vida familiar é estruturada e a consciência social encontra realização e expressão [...]: parentesco, costume, as regras visíveis da regulação social, hegemonia e dependência, formas simbólicas de dominação e da resistência, fé religiosa e impulsos milenaristas, maneiras, leis, instituições e ideologias - tudo o que, em sua totalidade, compreende a 'genética' de todo o processo histórico, sistemas que se reúnem todos, num certo ponto, na experiência humana comum, que exerce ela própria (como experiências de classe particulares) sua pressão sobre o conjunto."

${ }^{4}$ Neste texto não se está usando a definição formal da região do Alto Uruguai do RS usada por órgãos oficiais. Entende-se por Alto Uruguai uma região ampla, que abrange boa parte do norte do RS, colonizada por imigrantes, com predominância de pequenas propriedades e certa unidade cultural.
} 
ação estatal. Dentre as principais transformações estruturais ocorridas na década de 1970, Gonçalves Neto (1997, p. 141) destaca o rápido processo de urbanização que transformou o país de rural em urbano; o crescimento acentuado do comércio exterior; a alteração da base técnica da produção rural, com ampla absorção de capital; e a definição de um sistema nacional de crédito e assistência técnica rural, que motivou e sustentou o processo de modernização do setor agrário. Como resultado deste processo, ainda de acordo com esse autor, ocorreu, de um lado, a "transformação da base técnica em boa parte do setor agrário, no que se convencionou chamar de modernização desigual" (p. 224-225, grifos no original), privilegiando os grandes proprietários de terras; as culturas voltadas para o mercado externo; as regiões mais desenvolvidas do centro-sul e atingindo apenas uma parcela de agricultores que tiveram crédito subsidiado (em torno de 20 a 25\%). E, de outro lado, promoveu a formação dos complexos agroindustriais, constituídos por um conjunto de empresas de produção de insumos modernos, máquinas, equipamentos, fertilizantes, defensivos, medicamentos veterinários etc. situadas a montante do setor agropecuário; e empresas para compra, transformação e comercialização da produção agrícola, antes de atingir o consumidor, situadas a jusante do setor.

No Planalto Gaúcho, estas políticas de modernização promoveram grandes mudanças no modo de produzir e de viver dos agricultores, com destaque para a especialização produtiva (principalmente no binômio trigo-soja) e a modernização tecnológica das lavouras com o uso de maquinários, agroquímicos e sementes híbridas. Para impulsionar a modernização da agricultura, o principal vetor utilizado foi a política de "assistência creditícia" (BRUM, 1988). O Sistema Nacional de Crédito Rural ${ }^{5}$, ao conceder crédito, subordinava o agricultor à fiscalização e à assistência técnica dos órgãos oficiais. Nessa lógica, estimulou-se a adoção de pacotes tecnológicos da chamada Revolução Verde, então considerados sinônimos da moderna agricultura, e "incentivou-se um enorme aprofundamento das relações de crédito na agricultura, mediando a adoção desses pacotes com volumosas subvenções financeiras" (DELGADO, 2004, p. 13).

A política agrícola beneficiou, sobretudo, as culturas denominadas dinâmicas, aqueles produtos mais diretamente ligados à indústria e à exportação, em detrimento dos cultivos de subsistência. Muitas áreas destinadas ao cultivo de produtos alimentícios básicos foram substituídas por lavou- ras de monocultura, para o suprimento de agroindústrias ou do mercado externo. Este formato de agricultura passou a produzir, em grande escala, aquelas culturas cujos preços altos no mercado garantiam lucro certo em tais empreendimentos. O Estado estimulou esses setores competitivos, praticamente abandonando aquelas culturas que se têm constituído, historicamente, na alimentação básica dos brasileiros. Como afirmam Martine e Garcia (1987, p. 83): "O favorecimento de culturas 'dinâmicas' para exportação e/ou para as agroindústrias relegou a produção de gêneros de primeira necessidade, particularmente de feijão, mandioca e arroz, essenciais à sobrevivência dos estratos de renda mais baixa, a um status secundário".

Estas orientações produziram a especialização dos agricultores no Planalto Gaúcho na produção do binômio trigo-soja (trigo no inverno e soja no verão, fazendo uso das mesmas áreas de terras e máquinas). A adoção destes cultivos e dos pacotes tecnológicos a eles associados fez com que os agricultores experimentassem fortes mudanças nas formas de produzir e de viver:

Da enxada, do arado de tração animal e da carroça, passou-se ao trator, à automotriz, ao caminhão, ao automóvel etc. Rompeu-se o ritmo lento do meio rural marcado pela tradição. Aumentou a velocidade do sistema de produção, bem como dos contatos e das informações. A visão do mundo ampliou-se, abarcando não apenas o distrito ou o município, mas o Estado, o País, e o plano internacional (BRUM, 1988, p. 122).

O projeto de modernização técnica teve seu auge durante os anos 1970. Após um ciclo de crescimento (onde o Produto Interno Bruto cresceu a uma taxa de $8,1 \%$ em média - no período de 1965/80), a economia brasileira enfrentou "uma dura crise recessiva a partir de 1981, cuja manifestação mais direta é a reversão dos fluxos de financiamento externo após a moratória mexicana de 1981" (DELGADO, 2004, p. 16-17). O custo do endividamento exterior, somado à conjuntura desfavorável da economia mundial, levou a que, no início da década de 1980, se vivenciasse no Brasil uma conjuntura de crise generalizada em amplos setores. O setor agropecuário foi um dos mais atingidos.

Este processo de modernização passou a ser fortemente contestado a partir do final dos anos 1970, seja por

${ }^{5}$ O sistema de crédito foi criado em 1965, mas teve maior atuação na década de 1970 (GONÇALVES NETO, 1997). 
agricultores dele excluídos e suas organizações de representação, seja por técnicos e estudiosos da questão agrária. Sindicatos, Igrejas, ONGs e academia produziram críticas ao modelo de desenvolvimento autoritário, excludente e insustentável constituído pelas políticas de modernização da agricultura no período do regime militar (ALMEIDA, 1989; BRANDENBURG, 1999; SCHMITT, 2001; DIAS, 2004). O modelo de agricultura da modernização mostrava a sua face mais perversa para os agricultores de base familiar do Sul na década de 1980. Schmitt (2002) destaca a situação insustentável e os impasses em que se encontravam: a especialização excessiva, a dependência em relação a insumos externos, a fraca integração entre os diferentes sistemas de cultivo e criação, a perda das variedades localmente adaptadas, a erosão do conhecimento sobre o manejo da biodiversidade local, a degradação da qualidade do solo e da água e a crescente desvalorização das atividades e dos produtos destinados à subsistência das famílias agricultoras.

As ações de questionamento a esta situação também resultaram em iniciativas de construção de alternativas organizativas e formas de produzir para pensar novos horizontes para os pequenos produtores com dificuldades de manterem-se na atividade agrícola e pensar um novo modelo para o campo. Neste sentido, foram importantes as ações da Comissão Pastoral da Terra (CPT) na região Sul e um conjunto de ONGs que formaram a Rede de Tecnologias Alternativas/Sul (REDE TA/SUL, 1997; BRANDENBURG, 1999).

A Rede Tecnologias Alternativas/Sul (Rede TA/Sul) surgiu de uma articulação de ONGs ambientalistas que iniciaram a organização de um "movimento contestatório ao processo de modernização da agrícola" (REDE TA/ SUL, 1997, p. 177). A origem dessa articulação se deu com a criação do Projeto Tecnologias Alternativas (PTA) pela Federação de Órgãos para Assistência Social e Educação (FASE), em 1983'. Em 1989, este Projeto deu base para a criação de uma organização independente, a Assessoria e Serviços a Projetos em Agricultura Alternativa (AS-PTA), realizando trabalhos nas regiões Sul, Sudeste e Nordeste do país. Especificamente na região Sul, se criou a Rede TA/ Sul como "uma rede de entidades não governamentais, sem fins lucrativos e de caráter não partidário ou religioso, que desenvolve trabalhos de pesquisa, assessoria, formação e difusão na área de tecnologias alternativas para a agricultura." (REDE TA/SUL, 1997, p. 170). A rede foi formada por conjunto heterogêneo de organizações no três estados do Sul, com trajetórias próprias, a saber:

A Igreja Evangélica de Confissão Luterana do Brasil (IECLB) criou, em 1978, o Centro de Apoio ao Pequeno Agricultor (CAPA), que atua nas regiões de Santa Cruz do Sul e São Lourenço e Erechim. Na região de Passo Fundo, a partir da reivindicação dos movimentos populares, surge em 1986 o Centro de Tecnologias Alternativas Populares (CETAP), com sede em Passo Fundo. Também no Rio Grande do Sul, a partir das lutas socioambientais, é criado em 1985 o Projeto Vacaria, posteriormente denominado de Centro de Agricultura Ecológica (CAE-Ipê). Na região Celeiro do Rio Grande do Sul existe o trabalho da Fundação de Desenvolvimento, Educação e Pesquisa da Região Celeiro/Departamento de Educação Rural (DER-FUNDEP), com sede em Braga. De forma similar, com trajetórias diferentes, porém com objetivos comuns, surge o Centro Vianei de Educação Popular, sediado em Lages-SC, e a Associação dos Pequenos Agricultores do Oeste Catarinense (APACO), com sede em Chapecó-SC. No Paraná, além do trabalho da AS-PTA, a Associação de Estudos, Orientação e Assistência Rural (ASSESSOAR) e a Fundação para o Desenvolvimento Econômico Rural da Região Centro-Oeste do Paraná (RURECO) têm realizado trabalhos com agricultores familiares e agroecologia, sendo a base de suas atuações os movimentos sociais organizados desde Estado (REDE TA/SUL, 1997, p. 177).

As organizações que compõem a Rede identificam-se como construtoras de um "novo modelo de desenvolvimento rural" que priorize os pequenos e médios produtores familiares livremente associados no processo de produção, beneficiamento e comercialização; leve em conta o potencial de cada agroecossistema; regionalize as estruturas de beneficiamento e transformação dos produtos (REDE TA/ SUL, 1997).

Ao analisar as ações deste conjunto de ONGs articuladas em uma rede, Brandenburg (2002) chama atenção para a importância do seu trabalho para sobrevivência dos agricultores e a reconstrução de sua relação com a natureza:

\footnotetext{
${ }^{6}$ A concepção de tecnologia alternativa que teria guiado o PTA, segundo Almeida (1989, p. 208), foi: "aquela que, atendendo aos interesses do pequeno produtor rural, reforça sua capacidade de resistência na terra, de melhorar sua organização, seu poder de enfrentamento das forças econômicas e políticas adversas, de melhorar seu padrão de vida e segurança econômica."
} 
Essas organizações desenvolveram um serviço de assistência aos agricultores numa perspectiva política crítica à modernização da agricultura. Sob o ponto de vista técnico, resgatam-se práticas tradicionais e já conhecidas dos agricultores, visando compor um conjunto de estratégias que permitiriam a reprodução social dos agricultores no campo. A agricultura alternativa representa uma opção de sobrevivência para o agricultor familiar e significa a reconstrução de uma relação socioambiental cuja raiz tem origem na condição camponesa (BRANDENBURG, 2002, p. 2).

Na região do Alto Uruguai do RS destacou-se a atuação principalmente do CETAP no assessoramento das organizações de agricultores. O CETAP, segundo é apontado pelo seu próprio jornal informativo, Agricultura Alternativa, surgiu para suprir as necessidades de "buscar alternativas concretas aos agricultores" em um momento de crise:

É neste contexto de graves consequências geradas pelo processo de modernização e investida do capitalismo no campo e pela necessidade de buscar alternativas concretas aos agricultores que os Movimentos Sociais, sindicatos e entidades ligadas ao meio rural passaram a discutir, em meados da década de 80 , a necessidade de se criar um órgão de pesquisa e assessoria aos pequenos produtores. [...] os Movimentos Sociais organizados, durante o I Encontro Estadual de Tecnologias Alternativas, ocorrido em Passo Fundo, de 23 a 25 de janeiro de 1986, decidem criar o CETAP - Centro de Tecnologias Alternativas Populares (AGRICULTURA ALTERNATIVA, 1991, p. 3).

Desde o seu surgimento, o CETAP tem por "função desenvolver atividades de resgate, experimentação e difusão de Tecnologias Alternativas que fortaleçam a pequena produção e preservem o meio ambiente" (AGRICULTURA ALTERNATIVA, 1991, p. 3). O CETAP esteve no centro dos debates e da construção de experiências práticas relacionados à temática da agricultura alternativa ou ecológica desenvolvida pelo sindicalismo rural da CUT, pelo Movimento dos Trabalhadores Rurais Sem-Terra (MST), pelo Movimento dos Atingidos por Barragens (MAB) e pelo Movimento de Mulheres Trabalhadoras Rurais (MMTR) na região do Alto Uruguai do RS.

O sindicalismo rural da CUT tem sua origem articulada com o surgimento dos outros movimentos sociais do campo no final dos anos de 1970 e no início da década de 1980 (como MST, MAB e MMTR, que nasceram no mesmo caldo cultural). No RS, teve início com a formação de oposições sindicais aos sindicatos ligados à Federação dos Trabalhadores na Agricultura do RS (FETAG-RS). Em alguns municípios em que os pequenos agricultores enfrentavam fortes dificuldades relacionadas a preços baixos de produtos agrícolas, falta de terras para as novas gerações, situações de agricultores que seriam atingidos por obras de barragens, entre outras, surgiu um movimento contestador das linhas políticas assumidas pelo sindicalismo e das diretorias dos sindicatos. Conformou-se uma concorrência em torno do sindicalismo, um "campo político" (BOURDIEU, 2007) onde os agentes desafiantes, que se articulavam nas chamadas oposições sindicais, acusavam as direções estabelecidas de serem acomodadas frente aos problemas dos agricultores, de serem antidemocráticas por centrarem-se nas figuras dos presidentes sem haver mecanismos de discussão com as bases sobre os seus problemas com a ação sindical, de serem órgãos assistencialistas ligados aos governos para prestação de serviços de saúde, previdência, entre outras críticas. Além disso, alguns sindicatos e a própria FETAG eram acusados de serem corresponsáveis pelos problemas causados pelas políticas de modernização da agricultura e que afetavam os pequenos agricultores naquele momento, na medida em que a Federação e seus sindicatos haviam apoiado e/ou continuavam apoiando as políticas de modernização mantendo relações próximas com os governos. As oposições sindicais, que viriam a formar a CUT rural, combatiam esse tipo de postura e argumentavam que queriam constituir um novo sindicalismo surgido dos interesses coletivos dos agricultores, "um sindicalismo 'autêntico', 'combativo', capaz de representar efetivamente as 'bases", (SCHMITT, 1996, p. 193).

A conquista dos primeiros sindicatos se deu nos anos de 1983-84, em municípios como Miraguaí, Erechim, Tenente Portela, Rodeio Bonito e Erval Seco, todos situados na região do Alto Uruguai. Com novas conquistas de sindicatos e aproximação de outros considerados mais atuantes, foi se formando um movimento de renovação do sindicalismo em algumas regiões do Estado, gerando tencionamentos e disputas dentro da estrutura sindical da FETAG-RS. Após tentativas frustradas de conquistar a direção da FETAG, os cutistas decidem formar uma estrutura organizativa paralela no Estado com a formação do Departamento Estadual de Trabalhadores Rurais em 1990 (antes disso, já existia uma Secretaria dos Rurais desde 1984), seguindo uma orien- 
tação nacional da CUT que, em 1988, já tinha formado o Departamento Nacional de Trabalhadores Rurais (DNTR) ${ }^{7}$.

Desde a sua origem, em meados dos anos de 1980, alguns sindicatos cutistas já procuravam tratar não apenas de reivindicações dos agricultores, mas também de problematizar questões relacionadas à produção e às tecnologias usadas na agricultura (alternativas produtivas). Como aponta Almeida:

No Rio Grande do Sul, alguns sindicatos de trabalhadores rurais localizados na região do Alto Uruguai (norte do Estado), iniciaram a discussão sobre a questão tecnológica, colocando o problema da inadequação da pesquisa agrícola, da assistência técnica e da extensão rural, inadequadas que são aos pequenos agricultores e voltadas especialmente para os "produtos de exportação". Juntamente com essa crítica, fazem a condenação da "agricultura insumista", ou seja, aquela que usa intensamente corretivos de solo, adubos e agrotóxicos, encarecendo o custo de produção e poluindo o meio ambiente (1989, p. 204-205).

Essa posição mais genérica e difusa de condenação da agricultura insumista pelo sindicalismo foi aprofundada a partir do início da década de 1990. Com a realização do II Congresso estadual DETR, em 1993, foi tomada a decisão política de partir para uma etapa de organização da produção e de formulação de um projeto para o campo com base "no resultado das experiências concretas vivenciadas pelos trabalhadores desde a base e da reflexão política articulada do conjunto da CUT e de seu campo de alianças" (DETR-RS, 1993, p. 11). Com a formulação deste projeto para o campo, pretendia partir para uma tática de ação sindical não mais somente de "caráter reivindicatório e contestatório" (DETR-RS, 1993, p 11), mas tratava-se de elaborar uma "proposta alternativa de desenvolvimento rural" que servisse para "definição de pautas concretas de reivindicação e negociação" (DETR-RS, 1993, p. 11). Este novo modelo de agricultura a ser construído, além de ter por metas forta- lecer os agricultores familiares e apoiar a reforma agrária, implicava em fazer escolhas tecnológicas que levassem em conta preocupações ecológicas e culturais. Nas resoluções do II Congresso já eram apresentados alguns indicativos do que seria esse projeto, que passaria a embasar o projeto cutista para o campo:

Um Projeto Alternativo de Desenvolvimento que garanta a viabilização da Agricultura Familiar implica em: a) um novo modelo tecnológico que leve em conta as questões sociais e ecológicas da produção agrícola; b) novas formas de organização da produção, comercialização, beneficiamento da produção e abastecimento; c) reforma agrária enquanto instrumento para transformação do atual modelo de desenvolvimento da agricultura brasileira; d) política agrícola diferenciada para o pequeno agricultor; e) pesquisa e extensão rural voltados para o interesse dos trabalhadores; f) construir as bases culturais de um desenvolvimento alternativo, resgatando valores como a solidariedade, a cooperação e estabelecendo uma nova relação homem-natureza (DETR-RS, 1993, p. 14-17, grifos nossos, ELP) ${ }^{8}$.

Com a decisão de unificar o sindicalismo rural brasileiro por intermédio da entrada do DNTR na estrutura da CONTAG (e os DETRs dos Estados nas FETAGs) e a filiação da Confederação à CUT em 1995, esta proposta de construção de projeto alternativo de desenvolvimento rural, que vinha sendo construída no interior do sindicalismo cutista, passou a ser adotada pelo conjunto do sindicalismo dos trabalhadores rurais em nível nacional ${ }^{9}$. Acompanhando estas mudanças na estrutura do sindicalismo rural brasileiro também ocorreu a emergência de uma nova categoria de identificação, que passou a unificar boa parte do sindicalismo: a agricultura familiar.

Para Medeiros (2001), a afirmação da identidade de agricultor familiar como unificadora de boa parte do sindicalismo relaciona-se a uma série de fatores: ao aumento da importância dos pequenos produtores no interior do

\footnotetext{
${ }^{7}$ Em uma publicação da CUT, é relatado como ocorreu o processo de constituição de sua estrutura interna: "O início da construção da CUT se deu pela constituição de sua estrutura horizontal, formada pelas CUTs estaduais e regionais. Em 1986, no II CONCUT, foi aprovada a constituição da estrutura vertical, que tinha duas características principais: a base da representação seria o ramo de atividade econômica; as estruturas de representação seriam os departamentos, nacional e estaduais. [...] A V Plenária Nacional da CUT, realizada em 1992, aprovou a transformação dos departamentos em confederações/federações orgânicas CUT e indicou a constituição de 18 ramos: rurais; metalúrgicos; bancários; químicos; comerciários [...]” (CUT, 2002, p. 7-8).

${ }^{8}$ Este debate de construção de um Projeto Alternativo de Desenvolvimento também ocorria neste mesmo período no Fórum Sul dos DETRs (que abrangia o sindicalismo rural cutista dos três Estados do Sul) e em nível nacional no DNTR/CUT. Maiores detalhes sobre este debate ver Picolotto (2011).

${ }^{9}$ As bases desse projeto podem ser encontradas no documento Projeto Alternativo de Desenvolvimento Rural Sustentável (CONTAG, 1999).
} 
sindicalismo, que vinha ocorrendo desde a década de 1980; à reivindicação destes agricultores por um novo modelo de desenvolvimento centrado na agricultura familiar; ao aumento do debate intelectual sobre a temática; às atividades de formação e intercâmbios com países europeus visando conhecer suas experiências (promovidas pela Igreja e por ONGs europeias); e à criação de políticas públicas específicas, como o Programa Nacional de Fortalecimento da Agricultura Familiar (PRONAF), em 1996. Nesse sentido, a afirmação da categoria agricultura familiar fez emergir novos temas no interior do sindicalismo, renovando-o:

Temas antes eram considerados de menor importância, tais como a discussão de alternativas de comercialização, a experimentação de formas de produção associadas, o estímulo à constituição de agroindústrias, o significado e implicações das escolhas tecnológicas, as dimensões ambientais da produção agrícola, passaram a ser valorizados e a ganhar novos significados como sinalizadores de novos caminhos possíveis (MEDEIROS, 2001, p. 117).

Na região Sul, com a adoção da categoria de identificação agricultura familiar e com a conquista do PRONAF, ocorreu um processo de (re)organização e fortalecimento dos atores da agricultura familiar e de novo rompimento com a estrutura sindical da CONTAG na região. No Estado de Santa Catarina, devido a dificuldades dos cutistas trabalharem em conjunto com a federação sindical vinculada ao sistema CONTAG (FETAESC), eles decidiram criar uma organização própria, com a fundação da Federação dos Trabalhadores na Agricultura Familiar do Estado de Santa Catarina (FETRAFESC), em 1997, como representante específica dos sindicatos de agricultores familiares no Estado. A FETRAFESC solicitou filiação à CONTAG, mas não foi aceita. Seguindo esta experiência autônoma, considerada exitosa, e o relativo fortalecimento que a identidade política da agricultura familiar tinha alcançado, o sindicalismo rural da CUT na região Sul decidiu criar em 1999 a Frente Sul da Agricultura Familiar, como uma organização promotora da agricultura familiar na região (esta organização articulava sindicatos, cooperativas e ONGs). Dando sequência a esse processo de organização, foi fundada em 2001 a Federação dos Trabalhadores na Agricultura Familiar da Região Sul (FETRAF-Sul), como uma organização sindical específica de agricultores familiares. Essa proposta de um sindicalismo exclusivo de agricultores familiares foi nacionalizada com a criação da FETRAF-Brasil, em 2005.
Da articulação dos esforços das organizações de agricultores, setores de Igrejas e ONGs em prol de um novo modelo de desenvolvimento rural, foi formado um movimento para promover a valorização da agricultura familiar e a gestação de formas de produzir mais autônomas dos agricultores na região Sul. Como afirma Melucci, os movimentos sociais são como "profetas do presente", "anunciam aquilo que está se formando sem que ainda disso esteja clara a direção e lúcida a consciência" (2001, p. 21). Nesse sentido, a identidade da agricultura familiar dava unidade a este conjunto diverso de atores, ao mesmo tempo em que possibilitava projetar um objetivo comum (uma utopia), que era a busca do reconhecimento da sua importância socioeconômica através do fortalecimento da sua identidade social, de organização política e da construção de um projeto alternativo de desenvolvimento centrado na agricultura familiar.

Referindo-se à proposta de um novo modelo de desenvolvimento rural encampado pela FETRAF-Sul, Altemir Tortelli, seu coordenador geral, afirma ser necessário:

\begin{abstract}
Além de construir um sindicato forte, de construir um grande embate com o Estado, com os governos e avançar nas políticas públicas [...] nós também precisaríamos construir, na vida real, lá na comunidade, na propriedade, uma outra forma de pensar a produção, de pensar a relação do homem com a natureza, do homem com o meio, do homem e a família com a propriedade, com a terra, com os meios de produção, com o maquinário, com o mercado, com a transformação daquilo que nós produzimos. (Entrevista ao autor, 2010).
\end{abstract}

Outro dirigente da FETRAF-Sul, ao relatar o que seria o projeto da Federação, aponta as suas preocupações de manter o agricultor familiar em sua atividade, propiciando-lhe conhecimentos e qualidade de vida:

Nosso projeto é manter o agricultor lá na roça. Fazer do local de trabalho um modo de vida. Fazer com que ali, naquela propriedade, tenha renda, tenha condições de vida e que ele entenda de mercado, conjuntura. Ele saiba tomar decisões a cada mês, a cada dois, sobre para onde é o melhor caminho dele. Então, o nível de conhecimento tem que aumentar muito, e ali é onde que nasce de qualquer maneira a dificuldade. Então, construa um projeto de desenvolvimento sustentável e solidário, para a agricultura familiar. Necessariamente ele passa 
por estar entendendo a família dele e entendendo a propriedade dele [...]. Construir o nosso projeto de desenvolvimento que passa então pela agroindústria, pela questão da agroecologia, pela questão de produção de sementes. E, então, passa pela questão de gênero, pela questão da participação dos jovens, pela questão do mercado solidário. (Celso Ludwig apud RODRIGUES, 2004, p. 58).

O projeto de desenvolvimento da Federação pretende articular a busca da construção de um modelo agrícola sustentável, diversificação das fontes de renda, direitos de cidadania, participação ativa dos jovens e das mulheres e a promoção de mercados solidários. Nesse projeto, emerge como um tema central a construção e a disseminação de práticas agrícolas com base nos preceitos da agroecologia.

Em suas declarações públicas, a FETRAF oferece uma definição do que compreende como agroecologia, entendendo-a como "um processo de produção de alimentos numa relação de respeito entre seres humanos e destes com a natureza, que se dá sem pacotes tecnológicos e insumos industriais, sem agressão ao meio ambiente, utilizando-o para promoção da qualidade da vida nos ecossistemas" (FETRAF-SUL, 2002, p. 7). Então, diante desta concepção, afirma escolher as formas agroecológicas de produção de alimentos como base para promover o "desenvolvimento rural sustentável, [que] pressupõe uma ética de respeito ao conjunto da natureza, entendendo os seres humanos como parte dela, envolvendo as dimensões social, econômica, política, tecnológica, ambiental e cultural" (FETRAF-SUL, 2002, p. 7).

No Documento Base do III Congresso da FETRAF-Sul, é destacado que a Federação "vê o tema ambiental numa perspectiva multidimensional", na perspectiva do "desenvolvimento humano e sustentável" (FETRAF-SUL, 2010, p. 14). Nesse sentido, cobra dos governos políticas públicas e defende que se faça um esforço de "recuperação e preservação do meio ambiente, fortalecendo a agricultura familiar na perspectiva da sustentabilidade, orientando sua estratégia produtiva a partir dos seguintes princípios: agroecologia, diversificação, preservação da biodiversidade, policultivo e proteção às águas." (FETRAF-SUL, 2010, p. 14-15). No entendimento da FETRAF, a agricultura fami- liar, mesmo enfrentando muitas dificuldades no cenário atual, consegue manter uma relação mais harmoniosa com a natureza do que outras formas de exploração agropecuárias empresariais que só visam à extração de matérias-primas em uma relação predatória.

\section{Sindicalismo, agricultura familiar $e$ agroecologia em Constantina}

O despontar da ação política dos agricultores em Constantina se deu articulado com a construção de uma rede de movimentos de luta por terra, de renovação do sindicalismo e de construção de experiências de agricultura alternativa, tratada no item anterior. Assim como em outros locais do país, a atuação de agentes da Igreja Católica foi um importante desencadeador da mobilização política dos agricultores também em Constantina. O trabalho de formação de Comunidades Eclesiais de Base (CEBs), promovido por sacerdotes e leigos da Igreja identificados com a Teologia da Libertação, teve forte expressão local, principalmente no trabalho de formação política junto aos jovens rurais (PICOLOTTO, 2006).

A crítica às práticas do sindicalismo rural foi a pauta que inicialmente mais impulsionou a ação política de jovens lideranças de comunidades rurais. Avaliavam que a direção do Sindicato de Trabalhadores Rurais (STR) pouco fazia para ajudar a resolver os problemas (baixos preços dos produtos agrícolas, falta de terras para as novas gerações etc.) dos pequenos agricultores naquela conjuntura difícil do início da década de 1980: "O Sindicato era 'pelego', era só ficha pra consulta, pro dentista. Não tinha iniciativa de construir luta" (entrevista de Valdecir Lazzaretti, ex-presidente do STR, 2005). Partindo deste entendimento, as jovens lideranças, assessoradas por agentes católicos, fizeram uma articulação política nas comunidades rurais ${ }^{10}$ do município em favor da renovação da direção do Sindicato, disputaram uma eleição e saíram vitoriosos no ano de 1986. Nesse mesmo ano, as oposições sindicais cutistas conquistaram na região o STR de Palmeira das Missões e no ano anterior haviam conquistado o Ronda Alta e o Sarandi (SCHMITT, 1996).

\footnotetext{
${ }^{10} \mathrm{O}$ município de Constantina, assim como outros municípios das regiões de colonos, é organizado no meio rural em forma de comunidades ou linhas (como também são chamadas). Ao que tudo indica a origem destas comunidades ou linhas se deu ainda com o processo de implantação das colônias no início do século XX, quando os colonos formaram comunidades de capela para construir igrejas e escolas.
} 
Conjuntamente com outras organizações de agricultores da região (como o MST, o MAB, o MMTR e outros sindicatos), o STR de Constantina organizou os pequenos agricultores na construção de grandes mobilizações de agricultores do final dos anos 1980. Estas mobilizações (trancamentos de estradas, passeatas em cidades importantes, ocupação de prédios públicos, acampamentos nas margens de rodovias, entre outras) visavam principalmente à reivindicação de políticas públicas e o reconhecimento de direitos de cidadania. A importância destas lutas é frisada pelas lideranças locais:

Então, foi importante esta questão da luta política contra os governos e de marcação de campo, que era importante construí uma política nova, de crédito, de financiamento, de custeio, na política da terra, na inclusão social. Então, surgiu daí vários movimentos e nos anos 1988, 89 e 90, foram os anos das maiores mobilizações da história, depois da ditadura militar, por parte dos agricultores. (Entrevista de Ivor Vicentini, ex-presidente do STR e de dirigente de cooperativa, 2005).

No que se refere à forma de encaminhar a luta pela construção de um modelo alternativo para os pequenos agricultores, o Sindicato foi além da postura reivindicatória, buscando avançar no aspecto propositivo com a realização de experiências ao nível local-regional. A ênfase em experiências locais foi resultante de um processo de aprendizado de que as lutas reivindicatórias não bastavam para viabilizar a pequena agricultura.

Depois de terminadas estas lutas iniciais nós também passamos a discutir sobre a agricultura, que não bastava só fazer lutas, nós precisávamos construir experiências próprias, alternativas, na questão da agricultura. E paralelo a isso, as organizações da nossa região criaram o CETAP, que vinha pra trazer suporte técnico e também político na questão da agricultura. Então, resolvemos fazer aqui em Constantina, em conjunto com o CETAP, algumas experiências na área de adubação verde e sementes. (Entrevista de Ivor Vicentini, 2005).

O CETAP foi criado para oferecer assistência técnica aos agricultores e às organizações, resgatar práticas agrícolas do passado dos agricultores que poderiam ser adaptadas às necessidades daquele período (como a adubação verde, a produção própria de sementes, o uso de controle natural para pragas como a lagarta da soja) e desenvolver novas tecnologias adaptadas às pequenas propriedades.

Nesse sentido, é destacado nas entrevistas que o trabalho de mudança das bases de organização e das técnicas de produção em Constantina só foi possível de ser iniciado após a conquista dos STR:

Em 1986 se conseguiu o Sindicato, então começa a mudar toda a conjuntura organizacional do município de Constantina e da região. Aí surgem as associações, os grupos de cooperação agrícola e começa o envolvimento dos agricultores. Os agricultores começando a fazer estágio no CETAP, buscando tecnologias alternativas diferentes do que se tinha até o momento. Porque os agricultores só sabiam criar porco, naquela época, plantar soja, milho e trigo e não se tinha uma outra alternativa que pudesse gerar renda pros agricultores. $\mathrm{E}$ assim foi crescendo a questão da organização. (Entrevista de Adir Lazzaretti, dirigente sindical e de cooperativa, 2004).

Assumindo o projeto de diversificação da produção e a busca de autonomia na atividade produtiva dos agricultores, foram organizados diversos grupos de agricultores (em associações de cooperação) e construídas diversas experiências de agricultura alternativa e de organização da produção com assessoria de técnicos do CETAP.

Se constituíram várias associações de cooperação agrícola que passaram a desenvolver experiência de forma coletiva algumas delas, outras de semente de milho, outras de adubação verde, enfim, e que teve um papel importante, por que o pessoal produzia a semente de milho e nós conseguia colocar toda a semente de milho. Se desenvolveu, por exemplo, criação de suínos ao ar livre, inicialmente, depois se parou, associações de máquinas, enfim, teve uma série de alternativas que foram sendo trabalhadas. (Entrevista de Ivor Vicentini, 2005).

Outra liderança também detalha experiências no município:

Então houve um movimento bastante grande em várias comunidades, resgate de adubação verde, recuperação de solos com plantas de adubação verde, digamos assim, adubação verde que é que nem a avica, mucuna. Porque 
isso procura a sustentabilidade da agricultura familiar, fazer com que o agricultor ele consiga também na produção ter sua independência, desde melhorar o solo, ter uma produção melhor, com isso, diminuir o custo. (Entrevista de Claudinei Tomazelli, 2005).

O auge destas associações se deu no início dos anos 1990, quando operavam 32 associações, abrangendo cerca de 320 famílias de agricultores.

Nos relatos das lideranças também é destacada a busca pelo resgate de experiências do passado, consideradas mais adequadas que as práticas agrícolas difundidas com a modernização agrícola. A produção de semente de milho própria e a adubação verde são exemplos disso. Enquanto no passado o agricultor tinha o domínio sobre a sua própria semente e fazia adubação com os recursos de sua própria propriedade, não ficava dependente das empresas de insumos químicos e sementes híbridas. Com a modernização, havia sido vendida a ideia de que as variedades de milhos híbridos eram mais produtivas, mas era necessário usar adubos químicos para alcançar esta maior produtividade. Então, nesse modelo moderno, o agricultor ficava dependente da compra de sementes e dos adubos. Para procurar diminuir a dependência do agricultor, eram desenvolvidas estas experiências.

A procura de bases para reformular a agricultura do período contemporâneo foi buscada nas formas de produzir do passado, ao mesmo tempo em que se orienta pelas preocupações do presente. Fazendo-se uma alusão à discussão sobre a "experiência" (THOMPSON, 1981), estas iniciativas dos agricultores e suas organizações de buscar alternativas em um momento de crise nas suas vivências históricas e formas de produção anteriores, mesmo depois de terem abandonado muitas delas no período da modernização, revela que a história de um grupo social não é linear ou lógica, mas, ao contrário, é formada por rupturas, continuidades, caminhos sinuosos e reinvenções de formas sociais, costumes, tradições e técnicas que já haviam caído em desuso, becos sem saída de onde é necessário se retroceder. É um processo constante de (re)criação.

Nesse sentido, outra iniciativa construída na busca de alternativas de reformulação do formato de produção agrícola foi a organização das associações de cooperação agrícola, baseada nos laços de cooperação entre os colonos que vêm de longa data. Em Constantina, estas associações foram organizadas entre os pequenos agricultores que moravam próximos (vizinhos), que já colaboravam entre si em trabalhos coletivos (como com os mutirões para o trabalho agrícola ou para construir alguma obra como casas, galpões, igrejas etc., na ajuda em forma de trabalho na roça às famílias com doentes, nas trocas de gêneros alimentícios entre vizinhos etc.) e entre grupos de agricultores em que alguns de seus indivíduos participavam de ações políticas chamadas pelo STR. As associações eram constituídas pelos grupos de agricultores que eram mais sensíveis à mobilização, seja por serem os que estavam em maiores dificuldades e por isso abraçavam a ação política, procurando alcançar solução aos seus problemas, seja por estarem dispostas a construir novas experiências de organização da produção coletiva e/ou de agricultura alternativa que eram estimulados pelo Sindicato e pelo CETAP. Diante disso, as associações - formadas em geral por um número que variava entre cinco e 30 famílias - eram entendidas como um instrumento de organização dos agricultores para resolverem juntos os problemas que enfrentavam. Além disso, era principalmente nas associações que se desenvolviam as experiências de agricultura alternativa e por isso recebiam atenção especial do STR e do CETAP.

No início da década de 1990, segundo relato das lideranças entrevistadas, as experiências de agricultura alternativa e de organização da produção citadas começavam a demonstrar que não eram suficientes para viabilizar os pequenos agricultores que estavam enfrentando fortes dificuldades de permanecer na atividade agrícola. De um lado, ficava evidente que as experiências conseguiram propiciar certa autonomia aos pequenos agricultores no que tange às sementes (mesmo limitadas a algumas culturas, principalmente o milho e adubação verde), no controle natural a pragas (como a lagarta da soja) e que estas fortaleceram a capacidade de iniciativa e de construção de ações coletivas entre as associações. Por outro lado, as lideranças entrevistadas destacaram que estavam tomando consciência de que estas experiências não conseguiram atender à principal necessidade que os pequenos agricultores tinham naquele período: fontes de renda que viabilizassem suas atividades. Ou seja, fazer as próprias sementes de milho, adubação verde, organizar associações não propiciava o desenvolvimento de fontes alternativas de renda para viabilizar economicamente os agricultores. $\mathrm{O}$ que se conseguia era reduzir os custos de produção de algumas culturas que, na maioria das vezes, eram de subsistência. Dessa forma, as principais fontes de renda continuavam sendo o plantio da soja e do trigo (culturas em que a adubação verde e a produção de sementes próprias eram de difícil aplicação) 
e a criação de suínos. Assim, não conseguiam romper com a dependência em relação aos agentes da agricultura especializada (representada localmente principalmente pela COTRISAL ${ }^{11}$ ).

Os dirigentes sindicais da época afirmam que, ao observar as limitações das experiências de agricultura alternativa, teriam percebido que parte dos problemas devia-se à falta de uma organização para incentivar e escoar a produção dos agricultores ${ }^{12}$. Com este diagnóstico, iniciou-se a discussão das possibilidades de construção de uma estrutura central, que agregasse as associações e que suprisse estes estrangulamentos (viabilizando a comercialização de outros produtos e permitindo uma forma de inserção mais favorável no mercado). Os dirigentes sindicais cogitavam a possibilidade de formar uma nova cooperativa que trabalhasse a diversificação produtiva.

O encaminhamento dado, então, foi a convocação de um seminário municipal para discutir a situação da pequena produção e a questão agrária no município. $\mathrm{O}$ seminário foi organizado pelo STR no ano de 1991, tendo contado com a participação de cerca de 400 agricultores e órgãos de assessoria, tais como CETAP, CPT e DESER. Logo após este evento, os agricultores, motivados pelo Sindicato, tomaram a decisão de formar uma cooperativa que trabalhasse com a atividade do leite. Segundo relato das lideranças, um elemento que motivou os pequenos agricultores a fundar uma nova cooperativa para trabalhar a atividade leiteira foi um fato conjuntural. A COTRISAL (cooperativa tradicional da região) estava impondo aos produtores de leite a obrigatoriedade de uma cota mínima de 50 litros a cada dois dias por produtor para continuar recolhendo o leite. Neste contexto, foi criada a Cooperativa de Produção Agropecuária Constantina Ltda. (COOPAC), fundada no ano de 1991, como contraponto à exclusão produtiva dos pequenos produtores de leite e como forma de estimular esta atividade como uma fonte de renda.

Após a fundação da nova Cooperativa, foi encaminhada a construção de um Posto de Recebimento de Leite e foi começado um trabalho de campo para estimular e qualificar a atividade leiteira. Dessa forma, os pequenos agricultores de Constantina buscaram solucionar as limitações das as- sociações de cooperação agrícola criando uma cooperativa de produção que propiciasse suporte, em princípio, para o desenvolvimento da atividade leiteira, considerada com potencial para gerar renda para as famílias agricultoras ${ }^{13}$. Outro elemento a ser destacado da fundação da COOPAC é que ela surgiu também como uma reação à exclusão dos pequenos produtores de leite pela COTRISAL. Ou seja, estes produtores de leite teriam sido motivados a criar uma estrutura alternativa para os pequenos frente aos grandes, que continuavam entregando sua produção à Cooperativa tradicional. Ficava evidente um recorte entre grupos diferentes de agricultores, com diferentes interesses, nessa iniciativa: os pequenos frente aos grandes produtores; uma cooperativa dos grandes e uma dos pequenos.

A fundação da Cooperativa para garantir a compra do leite dos pequenos agricultores foi divulgada pelo jornal do CETAP:

Com o posto será viabilizada a comercialização do leite, possibilitando o crescimento da bacia leiteira do município e arredores e principalmente ofortalecimento econômico dos produtores. A COOPAC fará a administração do posto e também será responsável pelo conjunto do projeto. Já foi iniciado um roteiro de reuniões nas associações visando à formação técnica dos produtores nesta linha de produção; formação e capacitação dos produtores são os objetivos centrais da COOPAC nesse momento. O CETAP vem contribuindo desde o início neste processo, assessoramento às discussões da direção e acompanhamento as reuniões com as associações (AGRICULTURA ALTERNATIVA, 1992, p. 6, grifos meus, ELP).

Em 1993, após a construção do Posto de Resfriamento de Leite, o número de produtores de leite do município, que era de 150 em 1991, havia mais do que dobrado. Neste ano, a COOPAC começou a operar com 300 produtores de leite, o que se deveu ao fato de a nova cooperativa ter procurado incluir todos os produtores de leite que existiam no município e estimulado outros a entrarem na atividade. Como atesta o depoimento de uma liderança: "aqueles

\footnotetext{
${ }^{11}$ O município de Constantina fica na área de atuação da COTRISAL (Cooperativa Tritícola Sarandi Ltda.). Esta Cooperativa é concebida pelas lideranças como um dos principais agentes da modernização da agricultura, incentivadora da especialização e, portanto, um adversário a ser combatido.

${ }^{12} \mathrm{O}$ Sindicato já vinha recolhendo a produção de semente de milho excedente para comercializar entre os agricultores. Mas estas ações se mostravam limitadas, tanto pela falta de estrutura do Sindicato para ampliar estes canais de comercialização alternativos quanto pela limitada produção destas sementes pelos agricultores.

${ }^{13}$ A viabilização da infraestrutura inicial da Cooperativa - para começar o recolhimento de leite - deu-se através de uma conjugação de ações e parcerias com o poder público local e estadual, além do voluntarismo dos agricultores interessados na viabilização da atividade leiteira através da COOPAC.
} 
que produziam cinco, dez litros, também entregaram e a COOPAC recebeu" (entrevista de Adir Lazzaretti, 2004) ${ }^{14}$.

A comercialização do leite foi viabilizada, inicialmente, por intermédio da Cooperativa Estadual de Lácteos e Correlatos (CORLAC) ${ }^{15}$, que garantia o escoamento da produção. A possibilidade de escoamento garantido e o relativo sucesso na ampliação da produção e do número de produtores deram base para um entusiasmo que teria persistido até o ano de 1997, quando a CORLAC foi reestruturada e a Cooperativa de Constantina precisou buscar um caminho próprio para comercialização do leite. O novo caminho, segundo relatos das lideranças, começou com a realização de um planejamento das atividades da COOPAC para três anos, com assessoramento do Centro de Apoio ao Pequeno Agricultor (CAPA) de Erechim (ressalta-se que o CAPA também fazia parte da Rede TA/Sul). A partir daí, a COOPAC passou a trabalhar a formação de uma marca própria de leite e do estabelecimento de um escritório para comercializar sua produção na região metropolitana de Porto Alegre. Com a realização do planejamento, surgiu a ideia de expandir a atuação da Cooperativa a outros produtos da agricultura familiar, buscando viabilizar mais fontes alternativas de renda às famílias. Considerou-se que já estava aberto um canal de comercialização de leite na região metropolitana e por meio deste poderia ser viabilizada a comercialização de outros produtos. Do mesmo modo, poderiam ser incentivadas outras formas de comercialização, como as feiras. Optou-se por incentivar a produção de produtos orgânicos ou agroecológicos, tendo em vista a busca de culturas limpas e a exploração deste nicho de mercado que se abria.

E a COOPAC também cria uma marca própria do leite, de 1997 pra cá. Entra no mercado, ela não depende mais de ninguém e continua o seu trabalho. Entra o soja orgânico, que é uma experiência bastante importante. $\mathrm{E}$ a COOPAC foi uma das pioneiras da região sobre o soja orgânico, o milho, o trigo. A COOPAC entra ali na produção familiar, com experiências de feira, a COOPAC começa a participar de feiras em Porto Alegre, pra cá, pra lá, venda de açúcar mascavo, compra dos produtores e vende pra fora, amendoim e pipoca. (Entrevista de Adir Lazzaretti, 2004).

Dessa forma, foram estabelecidas algumas bases político-organizativas locais para a viabilização econômica dos pequenos agricultores através do rompimento (mesmo que relativo) do circulo vicioso da dependência das grandes cooperativas tradicionais (da produção de trigo e soja). No entanto, com o fortalecimento da COOPAC, não se pode deixar de perceber que as associações de cooperação agrícola e toda a diversidade de experiências que estas desenvolveram passaram a ser colocadas em segundo plano ou reformuladas. Uma liderança que foi inicialmente um dos articuladores das associações e depois foi o primeiro presidente da Cooperativa reconhece isso quando afirma:

Um dos grandes problemas que hoje a gente avalia [...] é que daí todo aquele trabalho da cooperação agrícola se perdeu. Se perdeu aquelas experiências alternativas, por que quem tocava isso antes era eu e o Ideno [técnico agrícola] e nós viemos pra Cooperativa, os que ficaram no Sindicato não conseguiram tocar isso. (Entrevista de Ivor Vicentini, 2005).

Ou seja, o movimento dos agricultores tomou a decisão de construir uma cooperativa que propiciasse a viabilização de uma nova atividade produtiva rentável (leite) e com isso abriu mão, em grande medida, das outras experiências de agricultura alternativa e das associações de cooperação que eram células relativamente autônomas. Mas, também se deve reconhecer que a COOPAC igualmente incentivou a produção de culturas orgânicas, visando à diversificação da pequena agricultura, o que se relaciona diretamente ao fortalecimento da perspectiva de agricultura alternativa que começou com as associações. Neste aspecto, continuou se opondo à COTRISAL, um adversário forte que o Sindicato e as associações já vinham enfrentando:

\footnotetext{
${ }^{14} \mathrm{~A}$ importância desse trabalho da Cooperativa com a atividade do leite como alternativa de renda para os pequenos agricultores foi motivo de comemoração e ele foi escolhido para servir de exemplo para outros locais do RS. No ano de 1993, foi realizada em Constantina a $16^{\text {a }}$ Romaria da Terra (tendo inclusive iniciado a sua marcha no Posto de Resfriamento de Leite da COOPAC), com o tema "Organizando a Produção, Semeando Libertação" e contando com cerca de 20 mil pessoas presentes de todo o Estado (Agricultura Alternativa, 1993, p. 8). A realização da Romaria em Constantina justamente no ano em que a COOPAC iniciava o trabalho de recolhimento de leite evidencia a boa articulação que as lideranças locais tinham com outros atores no Estado e a importância que estes deram a essa iniciativa, considerada exitosa já em seu início.

${ }^{15}$ A CORLAC, que no início das atividades da COOPAC era uma empresa estatal, ainda no final de 1993 foi privatizada, passando ao controle de algumas cooperativas de pequenos agricultores do setor leiteiro. Mesmo com a privatização, esta continuou recolhendo e comercializando a produção leiteira das pequenas cooperativas.
} 
Então, a Cooperativa tem sua trajetória, ela passa a ter um papel importante porque ela passa a fazer frente à COTRISAL, que é uma cooperativa grande e que trabalhava com a exclusão dos seus cooperados. Um outro enfrentamento se deu na época porque nós defendemos a adubação orgânica, adubação verde e foi inclusive debate de rádio que eles eram contra, diziam que só o que resolvia era o adubo químico e nós dissemos que não. Logo depois eles pararam com essa briga e se consolidou na região este novo modelo de agricultura, conservação do solo e tal. Depois nós entramos com o soja orgânico, enfim, toda esta questão. (Entrevista de Ivor Vicentini, 2005).

Ao mesmo tempo em que a COOPAC continuou o esforço em prol do fortalecimento da produção leiteira e da diversificação da produção agropecuária, observa-se também um aumento do interesse pelos produtos considerados orgânicos e/ou agroecológicos. Nesse aspecto, deve-se ressaltar que em nível local o uso do termo orgânico ficou mais popularizado tendo em vista que foi através da produção da soja orgânica que foi iniciado o trabalho com toda uma série de outras culturas agrícolas que vieram depois, seguindo práticas de cultivo sem uso de insumos químicos.

Em 1998, a COOPAC, após realizar uma reunião com cerca de 50 agricultores, deu início a um programa pioneiro de produção de soja orgânica com 30 produtores participantes, em uma área de 48 hectares. Segundo relato de lideranças e técnicos, este trabalho inicial contou com assessoria do CETAP e da empresa Sustentagro, de Passo Fundo (ligada à produção de alimentos orgânicos e que viria a ajudar na comercialização da produção). O Jornal de Constantina registrou os motivadores do início da atividade:

Por presenciar quase que diariamente os problemas decorrentes do uso exagerado e indiscriminado de agrotóxicos pelos agricultores em suas propriedades, atitude que acaba causando sérios danos à saúde e ao meio ambiente, é que a direção da COOPAC começou a incentivar o cultivo de produtos agroecológicos (1998, p. 3, grifos nossos, ELP).

Em 1999, a inovadora experiência de produção de soja orgânica em Constantina foi noticiada pelo jornal de circulação estadual Correio do Povo, destacando as vantagens desse tipo de cultivo: "os custos de produção são mais baixos e o cultivo orgânico permite a utilização da mão de obra familiar" (1999, p. 14). Neste ano, foi ampliada a produção de soja orgânica, alcançando uma área plantada de 380 hectares e envolvendo 180 produtores (de Constantina e outros municípios vizinhos). A maior parte da soja orgânica foi certificada pelo Instituto Biodinâmico de São Paulo (IBD) e exportada para a Europa e a Ásia a um preço maior do que a convencional (CORREIO DO POVO, 1999, p. 14).

Um técnico agrícola, que foi um agente central na implantação desta experiência pioneira, destaca as vantagens que este tipo de produção propiciava aos agricultores:

Além da produção orgânica, que muitos produziam e não sabiam que era orgânico, tu acabava agregando um valor a mais porque era um produto saudável, conseguia vender esse produto com a agregação com um pouquinho a mais de valor. Queira ou não queira isso começou o debate, bom se eu vou plantar o soja convencional e vai ganhar, vamos dizer na época, 20 reais, eu posso ganhar 26 no orgânico e ainda vou envolver a mão de obra da família. O que vai fazer uma adequação que na verdade ia ter o não uso de agrotóxicos, preservação das águas, ter as matas nativas, ter as áreas de matas e tal para fazer barreiras de proteção do orgânico. Então se teve todo um debate aí que foi peliado. (Entrevista Nilto Lazzaretti, ex-técnico agrícola da COOPAC, 2010).

No relato do técnico, fica evidente que o trabalho de estímulo aos orgânicos não chegou a ser uma completa novidade, pois, como ele mesmo diz, "muitos produziam e não sabiam que era orgânico". Tratava-se dos agricultores que já desenvolviam práticas de agricultura que era chamada de agricultura alternativa em anos anteriores, que procuravam se livrar da dependência do uso de insumos. Para estes agricultores, o que mudou foi a categoria de nominação da agricultura que praticavam, que passava a ser chamada de orgânica, certificada para ser vendida em mercados específicos e passavam a receber maior retorno financeiro pela sua produção. Outros agricultores, naturalmente, foram atraídos para passar a produzir desta forma, tendo em vista que o retorno financeiro era maior e pelo fato de poderem fazer lavouras sem uso de agrotóxicos.

Outro elemento que chama atenção nesse relato é que com o cultivo orgânico se aproveitava a mão de obra das famílias agricultoras para a produção, não dependendo mais da contratação de serviços de máquinas para preparar e fazer os tratos culturais das lavouras (que era necessária na 
produção de culturas mecanizadas). Valorizava, portanto, o trabalho das famílias que trabalhavam diretamente em todas as etapas da produção, fazendo um trabalho de cultivo desde a semeadura até a colheita. Este envolvimento do trabalho da família nas atividades produtivas seria um exemplo do que seria de fato a agricultura familiar, ideia que vinha se gestando no interior do sindicalismo (nesse período em que se criava a FETRAF-Sul), como se refere uma liderança:

Se tu vai dizer pequeno agricultor parece que tu tá dizendo que é só o homem, lá $o$ pequeno agricultor. Então a agricultura familiar quer dizer que envolve homem, mulher e jovem. Então é uma agricultura familiar onde todo mundo faz parte. É essa a visão que nós tivemos no momento de dar o nome da agricultura familiar [com a criação da FETRAF-Sul], é quando toda a família participa do processo né, no processo da agricultura, no seu planejamento. (Entrevista de Dilva Brum, dirigente do STR, 2010).

Nestes depoimentos fica evidenciado como é apropriado do uso do termo agricultura familiar localmente, associado ao projeto do sindicalismo: associa-se a adoção do termo ao uso do trabalho da família nas atividades produtivas orgânicas, gerando um produto diferenciado, saudável, produzido pela força de trabalho da família agricultora; associa-se também ao fato de a produção neste formato de agricultura ser feita por todos os integrantes da família (homem, mulher e jovens) e não só pelo homem, como se referia o termo pequeno agricultor. A noção agricultura familiar ganha uma conotação associada ao projeto do sindicalismo de formar uma agricultura mais comprometida com a cidadania, com a valorização dos diversos sujeitos presentes na agricultura, com a produção de alimentos saudáveis e em harmonia com a natureza ${ }^{16}$.

A partir da terceira safra de soja orgânica em Constantina, a área plantada aumentou para mais de 606 ha e do ano 2000 em diante a produção orgânica direcionada a mercados que requeriam este tipo de produto cultivado de forma orgânica expandiu-se para outras culturas agrícolas, tais como: trigo, leite, milho, feijão, arroz, batata, carne e açúcar mascavo (CORREIO RIOGRANDENSE, 2001, p. 6). Com esse conjunto de experiências, se criaram condi- ções básicas para fortalecer os agricultores familiares pela diversificação das atividades produtivas promotoras de renda. Nas palavras de uma liderança:

Então, o agricultor começou a fazer açúcar, a plantar amendoim, pipoca, para vender pra COOPAC, a noz pecã ajuntar no chão e vender pra COOPAC. E daí cria debate da agricultura familiar e eu acho que este momento foi bastante rico. Bastante rico por que $a$ COOPAC dá a cara da agricultura familiar. (Entrevista de Adir Lazzaretti, 2004).

Entretanto, mesmo com essa expansão, estas experiências de produção orgânica tiveram fortes dificuldades para a sua continuidade a partir dos anos 2000 e 2001, fazendo com que a estratégia de diversificação da produção da agricultura familiar precisasse sofrer novas alterações para ter continuidade. Segundo o relato das lideranças entrevistadas, a partir do ano de 2000 começou-se a ter problemas na produção da soja orgânica devido a dificuldades de mercado, problemas com falta de outros produtos agrícolas orgânicos de grande rendimento (como a soja) para fazer rotação de culturas (passava-se a produzir só soja nas áreas, causando problemas produtivos) e, principalmente, devido à introdução de variedades de soja transgênica no município, que passaram a competir com a orgânica em rentabilidade e facilidade de cultivo e pelo fato de terem contaminado algumas áreas de cultivo orgânico. Com esses problemas, as lavouras de soja e trigo orgânico tiveram significativa retração, causando reações diversas entre os agricultores. Alguns, frente a estas dificuldades, voltaram a produzir soja de forma convencional, ao passo que outros seguiram nos orgânicos ou buscaram outras alternativas produtivas.

Paralelas ao incentivo aos produtos orgânicos, tiveram papel importante as políticas públicas de estímulo à geração de renda entre os agricultores familiares. Uma política criada com este intuito foi o programa de estímulo à formação e à qualificação de agroindústrias familiares durante a gestão de Olívio Dutra (1999-2002) ${ }^{17}$ no Governo do Estado, em parceria com organizações de agricultores, dentre elas a FETRAF. Em Constantina, com o acesso a esta política estadual, foram formadas algumas pequenas agroindústrias coletivas, principalmente com os grupos

\footnotetext{
${ }^{16}$ Um maior aprofundamento sobre a apropriação da noção de agricultura familiar pelo sindicalismo fetrafiano no Alto Uruguai do RS pode ser encontrado em Picolotto e Diesel (2008) e Picolotto (2011).

${ }^{17}$ O governo Olívio Dutra (Partidos dos Trabalhadores, PT) contava com apoio e até mesmo participação direta de quadros dos movimentos sociais e do sindicalismo rural na administração.
} 
remanescentes das antigas associações de cooperação agrícola. Estes grupos receberam cursos de capacitação do Estado e alguns deram início à atividade de processamento de matérias-primas de suas propriedades, tais como: cana-de-açúcar para produção de açúcar mascavo, cachaça e melado, queijos, salames, doces e sucos de frutas, entre outros.

Com as agroindústrias instaladas, logo foi percebido pelos agricultores e pelas lideranças do Sindicato e da COOPAC que as agroindústrias enfrentavam problemas para comercialização dos seus produtos. Visando suprir estas necessidades, em 2003 foi formada a Cooperativa dos Grupos de Agroindústrias dos Agricultores Familiares de Constantina e Região (COOPERAC), objetivando principalmente sanar os estrangulamentos na comercialização e na aquisição de embalagens ${ }^{18}$ para as agroindústrias.

A formação destas agroindústrias e da cooperativa que as congrega é associada pelas lideranças às primeiras experiências de formação de associações de cooperação agrícola do final dos anos 1980 e início dos 1990 (e também às mesmas famílias de agricultores), demonstrando que as experiências de organização e de produção do período mais recente mantêm fios de relação com as do passado, mesmo que revistos com os problemas contemporâneos. São experiências repensadas e reformuladas conforme as oportunidades que se apresentam, mas ainda mantêm relação com os objetivos de encontrar formas de viabilizar os agricultores do município.

Outra política pública que tem contribuído na diversificação da produção e na geração de renda entre os agricultores familiares de Constantina tem sido a sua participação no Programa Fome Zero. Em Constantina, por intermédio da COOPAC e da Prefeitura Municipal, começou-se, em 2004, o desenvolvimento de um projeto local operacionalizado por meio do Programa de Aquisição de Alimentos da Agricultura Familiar (PAA) da Companhia Nacional de Abastecimento (CONAB). A viabilização dos recursos necessários à consecução deste projeto se processou com a celebração de um convênio entre a COOPAC e a CONAB, que visa incentivar a agricultura familiar e é ao mesmo tempo uma ação estruturante do Programa Fome Zero, do Governo Federal. A operacionalização do Programa implica a definição de uma cesta básica, fornecida pelos agricultores e que é entregue quinzenalmente a famílias carentes e para a merenda escolar no município.
No ano de 2006, por exemplo, foram adquiridos de 254 famílias de agricultores 26 produtos diferentes para serem entregues nas cestas básicas e na merenda escolar. Dentre os produtos contemplados pelo Projeto estavam: açúcar mascavo, arroz, banha, batata-doce, batata-inglesa, beterraba, canjica, carne bovina, carne suína, cebola, cenoura, doce de frutas, farinha de milho, farinha de trigo, feijão, laranja, leite, mandioca, massa, mel de abelha, melado batido, ovos, queijo e repolho (COOPAC/CONAB, 2006).

Como se trata da produção de 26 itens alimentares diferentes, a participação dos agricultores familiares nesse Programa tem sido apontada pelas lideranças como extremante positiva para a diversificação da produção agropecuária no município, ajudar na comercialização dos produtos das agroindústrias, possibilitar um reforço na renda das famílias agricultoras, ajudar a solucionar o problema da fome entre os segmentos marginalizados da sociedade e fornecer alimentos de qualidade para a merenda escolar. Nesse aspecto, os agricultores familiares estariam ajudando a resolver o problema da fome, ao mesmo tempo em que estariam realizando sua missão histórica de produzir alimentos.

Além destas formas de comercialização estimuladas pelas políticas públicas, é usada também a estratégia de comercialização por intermédio de feiras. Parte da produção das agroindústrias e dos agricultores que produzem hortigranjeiros tem sido direcionada para uma feira semanal que tem sido organizada junto à sede do Sindicato e para feiras eventuais fora do município. Longhi e Santos (2003), avaliando a importância das feiras para o estímulo à diversidade da produção dos agricultores familiares atendidos pelo CETAP, destacam:

As Feiras Ecológicas desde o início vêm se destacando como espaços importantes de valorização da biodiversidade. O contato direto com os consumidores proporcionado pelas feiras mostra para o agricultor a importância da diversidade dos produtos ofertados, pois é assim que as bancas tornam-se atrativas. Do lado dos consumidores, percebe-se que estes também começam a valorizar uma série de produtos difíceis de serem encontrados no mercado convencional e que os agricultores costumavam produzir apenas para o consumo familiar (LONGHI; SANTOS, 2003, p. 8).

\footnotetext{
${ }^{18}$ A aquisição de embalagens em virtude da pequena escala de compra destes estabelecimentos era um empecilho grave, pois encarecia sobremaneira os produtos destes.
} 
No caso da feira de Constantina, estimulada pelo Sindicato, não se trata estritamente de uma feira ecológica, pois apenas uma parcela dos produtos ofertados na feira são apresentados como agroecológicos ou orgânicos, enquanto outra parte não segue este formato de produção. Entretanto, se nem todos os produtos podem ser considerados como agroecológicos ou orgânicos, a feira tem outro apelo que gera forte atrativo para os seus produtos, boa parte deles (ou quase a totalidade) são considerados como coloniais. $\mathrm{Ou}$ seja, são produtos elaborados de forma artesanal, segundo formas tradicionais de produzir herdadas dos antepassados, os colonos. São produtos considerados como tradicionais da região, tendo um apelo forte à tradição e ao costume, em oposição aos produtos industrializados, considerados artificiais. Como destacado por Longhi e Santos (2003, p. 8-9):

A importância que os consumidores têm dado aos chamados produtos coloniais deve-se, em grande parte, ao fato de que uma parcela significativa da população urbana da maioria das cidades brasileiras mantém ainda um forte vínculo com o meio rural, considerando que o êxodo rural no Brasil iniciou há pouco tempo, comparando-se com outras regiões do mundo. Isso faz com que muitos costumes sejam preservados e também, através das feiras ecológicas, muitos hábitos alimentares vão sendo resgatados, ao contrário da artificialização e alienação consumista promovida pelos sistemas de comercialização mercantis. (grifo no original).

As lideranças dos agricultores em Constantina também chamam atenção para este diferencial dos produtos coloniais e orgânicos, o seu potencial de se estabelecer como um produto diferenciado:

Temos que abrir mais espaços para a produção orgânica, até porque a tendência agora é de que as pessoas cada vez mais valorizem a saúde, então pra mim hoje vai ter muito espaço no mercado hoje de produtos orgânicos pra se vender. Então a relação da agricultura familiar com a agroecologia, eu acho que nós vamos avançar mais ainda é no momento que nós conseguir produzir mais produtos orgânicos, ecológicos. Porque vai ser o diferencial, senão nós não vamos conseguir competir né... Se eu vou fazer um salame convencional, eu vou comprar da Sadia, da Perdigão, da Seara, de outras empresas, muda o quê? Só se vender com preço mais barato né. Agora se eu produzir um produto diferenciado, colonial, orgânico, eu acho que dai vamos ter mercado, vai ter um mercado muito bom. (Entrevista de Adir Lazzaretti, 2010).

Pelo que se percebe, os produtos coloniais passam a ser valorizados não somente por serem elaborados de forma tradicional, mas também em alguns casos, quando a produção é feita de forma orgânica, por suas qualidades naturais, o que faz com que tenham um apelo por serem alimentos sadios, sem inclusão de insumos artificiais. Nesta acepção, ganham uma dupla qualificação, por serem produzidos de forma diferenciada, pelo trabalho artesanal da família agricultora e ainda por não conterem insumos artificiais prejudiciais à saúde. Seriam produtos social e ambientalmente corretos.

No aspecto da saúde, o movimento dos agricultores não tem intenção apenas de valorizar a saúde do consumidor dos produtos da agricultura familiar, mas também a das famílias agricultoras, pois como se refere a liderança Dilva Brum (que trabalha pelo Sindicato diretamente na área da saúde), "a saúde vem pela boca, as doenças vêm pela boca, então muitos tão comendo veneno", portanto, o cuidado com os alimentos consumidos seria uma necessidade urgente. Além do cuidado com a alimentação, é incentivada pelo Sindicato a busca de "remédios naturais" (entrevista de Dilva Brum). Desde meados dos anos 1990, o Sindicato (apoiado pelo Conselho Municipal de Saúde) tomou a decisão de montar uma farmácia natural, custeou a formação de uma de suas lideranças para atuar nessa área e passou a promover cursos sobre remédios naturais e sobre a qualidade dos alimentos entre as famílias agricultoras do município e de municípios vizinhos. Montou-se também (em parceria com a EMATER) duas hortas com plantas medicinais para produzir matérias-primas para elaboração dos remédios naturais (tendo em torno de 120 tipos de ervas diferentes).

Para o entendimento das lideranças entrevistadas, não bastava gerar renda aos agricultores de forma descomprometida com a saúde das famílias, portanto, esse trabalho sobre a qualidade da alimentação, de saúde preventiva e sobre remédios naturais é desenvolvido pensando na qualidade de vida das famílias agricultoras. Mas, esse trabalho também pode ser entendido como uma iniciativa de livrar os agricultores, mesmo que parcialmente, dos remédios de farmácia, os remédios industrializados. Da mesma forma que as organizações de agricultores e de assessoria procuram livrar o agricultor da dependência das indústrias de insumos e sementes na agricultura, procuram diminuir a dependência 
em relação aos remédios industriais. Nesse sentido, também com relação ao trabalho de saúde e qualidade de vida existe um apelo ao passado dos colonos (os antepassados), que viviam uma vida mais natural, mais saudável, sem usar venenos, com base em alimentação diversificada e, em função disso, tinham menos doenças que nos dias atuais. Estes hábitos mais saudáveis do passado, no entendimento das lideranças, podem embasar os debates sobre qualidade de vida no tempo presente.

\section{Considerações finais}

As preocupações ambientais estiveram presentes desde o início da trajetória do sindicalismo rural da CUT. Porém, o entendimento sobre esta temática sofreu alterações ao longo de seu caminho e mostra certas adequações às oportunidades políticas que foram se abrindo e à trajetória de criar/recriar as experiências do grupo social de agricultores (colonos) e das suas organizações. Da mesma forma, foram atribuídas importâncias distintas a aspectos particulares do tema ambiental ao longo do tempo. Neste aspecto, o estudo de caso em Constantina permite visualizar como as questões relacionadas ao ambiente foram tratadas em diferentes momentos pelo sindicalismo e as organizações de agricultores associadas a ele, preocupadas que estiveram com a viabilização econômica dos agricultores em diminuir a sua dependência das indústrias de insumos e com os impactos ambientais. Se em um primeiro momento o ataque às consequências negativas da modernização agrícola, a busca de saberes e técnicas de produzir do passado dos colonos e a produção de subsistência para as famílias eram o centro das suas ações, com o passar dos anos a diversificação produtiva e das fontes de renda para viabilizar os agricultores foram assumindo lugar central. É importante chamar atenção para o fato de que as estratégias de diversificação produtiva e de geração de novas fontes de renda tiveram em alguns momentos uma relação direta com a construção de uma agricultura de base ecológica (como na produção de soja e trigo orgânicos e na substituição dos insumos industriais pelos orgânicos), mas em outros momentos esta preocupação não esteve no centro de suas ações (como no estímulo à produção de leite e nas agroindústrias coletivas).

No período mais recente, também adquirem forte importância as políticas públicas de estímulo à renda dos agricultores, as preocupações com a diferenciação e a valorização dos produtos coloniais e orgânicos e com a saúde dos agricultores e consumidores. Enquanto os mercados institucionais gerados pelas políticas públicas têm garantido certa segurança na comercialização de um conjunto diverso de produtos e certa garantia de renda. As estratégias de diferenciação dos produtos da agricultura familiar e o apelo às qualidades tradicionais (artesanais) e orgânicas de seus produtos têm aberto alguns mercados diferenciados e alcançado certa valorização dos mesmos.

Ainda que a construção conceitual do que seria a agroecologia seja normalmente associada a um paradigma científico que vislumbra a transição dos atuais modelos de desenvolvimento rural e de agricultura para modelos mais sustentáveis ambiental e socialmente, as organizações de agricultores tratadas neste artigo têm concepções próprias de agroecologia. Na experiência dos agricultores de Constantina, a construção da agroecologia está normalmente relacionada à busca de viabilização socioeconômica e ambiental dos agricultores (principalmente os pequenos). Viabilização que se dá, seja por meio do uso de práticas agrícolas inspiradas nas usadas no passado - que permitem maior autonomia aos agricultores, que causam menores impactos ambientais e que estimulam a diversificação produtiva e das fontes de renda-, seja pelo cultivo de produtos diferenciados (como os orgânicos e coloniais) para venda e para consumo próprio, da agroindustrialização de matérias-primas e da venda para o Programa Fome Zero ou para a merenda escolar. Em geral, a preocupação ambiental é associada com a preocupação com a permanência do agricultor na sua atividade e com a qualidade de vida. Neste aspecto, se observa que as experiências relacionadas à agroecologia em Constantina assemelham-se a outros casos estudados entre os agricultores assentados ligados ao MST no Rio Grande do Sul, onde as experiências de agroecologia são entendidas de forma ampla, como associadas "à obtenção de alimentos, diversificação produtiva, soberania alimentar, independência dos produtores e, assim, a uma vida mais saudável.” (BARCELLOS, 2010, p. 79-80).

As preocupações ambientais e com a construção de formas de produzir com menores impactos no ambiente e na saúde dos indivíduos estiveram e ainda estão entre as preocupações centrais do sindicalismo dos agricultores familiares em Constantina e no sindicalismo da FETRAF-Sul em geral. A Federação, em suas orientações para os sindicatos e agricultores, recomenda que sejam adotados os princípios da agroecologia para construção de um modelo de agricultura mais sustentável, mas reconhece, ao mesmo tempo, as dificuldades que os agricultores da sua base 
enfrentam para fazer a transição para formas de produzir com menores impactos ambientais (a maioria ainda é dependente da produção de commodities para indústrias ou cooperativas empresariais). Nesse sentido, a agroecologia está mais para uma intenção, um projeto de longo prazo, do que para uma realidade concreta entre os agricultores de sua base. O que existe é uma orientação política da Federação e experiências entre alguns agricultores ou grupo de agricultores que passaram a trabalhar de forma orgânica

\section{Referências}

ALMEIDA, J. Propostas tecnológicas "alternativas" na agricultura. Cadernos de Difusão Tecnológica, v. 6, n. 2/3, maio/ dez, 1989.

ALONSO, A.; COSTA, V.; MACIEL, D. Identidade e estratégia na formação do movimento ambientalista brasileiro. Novos estudos CEBRAP, n. 79, nov. 2007.

BARCELLOS, S. B. A formação do discurso da agroecologia no MST. Dissertação (Mestrado em Ciências Sociais) - CPDA/ UFRRJ. Rio de Janeiro, 2009.

BOURDIEU, P. A representação política: elementos para uma teoria do campo político. In: . O poder simbólico. 10. ed. Rio de Janeiro: Bertrand Brasil, 2007.

BRANDENBURG, A. Agricultura familiar, ONGs e desenvolvimento sustentável. Curitiba: Ed. UFPR, 1999.

Movimento agroecológico: trajetória, contradições e perspectivas. Desenvolvimento e Meio Ambiente, Curitiba: Editora UFPR, n. 6, jul./dez. 2002.

BRUM, A. J. A modernização da agricultura: trigo e soja. Petrópolis: Vozes, 1988.

CAPORAL, F. R.; COSTABEBER, J. A. Agroecologia e desenvolvimento rural sustentável: perspectivas para uma nova extensão rural. Revista Agroecologia e Desenvolvimento Rural Sustentável, v. 1, n. 1, jan./mar. 2000.

DELGADO, G. Questão agrária brasileira no pós-guerra e sua configuração contemporânea. Rio de Janeiro: IPEA, 2004.

DIAS, M. M. As ONGs e a construção de alternativas para o desenvolvimento rural: um estudo a partir da Assessoria e Serviços a Projetos em Agricultura Alternativa (AS-PTA). Tese (Doutorado) - CPDA/UFRRJ. Rio de Janeiro, 2004. ou agroecológica e encontraram formas de produzir e viver dessa forma. Experimentações que tratam da substituição de insumos, preocupações com a saúde, com a diversificação das fontes de renda, entre outras. A agroecologia, nessa ótica, seria uma proposta do sindicalismo para a agricultura, uma proposta em construção e em diálogo com outros atores (academia, ONGs e o Estado), que enfrenta dificuldades para se consolidar como modelo de agricultura.

DIEGUES, A. C. Etnoconservação da natureza: enfoques alternativos. In: (Org.) Etnoconservação: novos rumos para a proteção da natureza dos trópicos. São Paulo: Napaub, 2000.

GONÇALVES NETO, W. Estado e agricultura no Brasil. São Paulo: Hucitec, 1997.

LONGHI A.; SANTOS, M. S. O CETAP e a biodiversidade. Passo Fundo: CETAP, 2003. Disponível em: $<$ http://www. cetap.org.br/wp-content/uploads/2008/11/o-cetap-e-a-biodiversidade.pdf $>$. Acesso em: 15/03/2010.

MARTINE, G.; GARCIA, R. C. Impactos sociais da modernização agrícola. São Paulo: Caetés, 1987.

MEDEIROS, L. S. "Sem-terra", "assentados", "agricultores familiares": considerações sobre os conflitos sociais e as formas de organização dos trabalhadores rurais brasileiros. In: GIARRACCA, N. (Org.). ¿Una nueva ruralidad en América Latina? Buenos Aires: CLACSO, 2001.

MELUCCI, A. A invenção do presente: movimentos sociais nas sociedades complexas. Petrópolis: Vozes, 2001.

PICCIN, M. B. Lógicas socioculturais e estratégias produtivas no Assentamento Menina dos Olhos dos Sem-Terra. Dissertação (Mestrado) - CPDA/UFRRJ. Rio de Janeiro, 2007.

PICOLOTTO, E. L. "Sem medo de ser feliz na agricultura familiar": o caso do movimento de agricultores em Constantina-RS. 2006. Dissertação (Mestrado em Extensão Rural) - UFSM. Santa Maria.

. As mãos que alimentam a nação: agricultura familiar, sindicalismo e política. Tese (Doutorado em Ciências Sociais) - CPDA/UFRRJ. Rio de Janeiro, 2011. 
; DIESEL, V. Implicações da apropriação da categoria "agricultura familiar" na trajetória da organização dos agricultores do Alto Uruguai do RS. Desenvolvimento em Questão, v. 6, n. 11, p. 41-67, 2008.

REDE TA/SUL. Interconectando ideias e ideais na construção da agricultura do futuro. In: ALMEIDA, J.; NAVARRO, Z. Reconstruindo a agricultura. Porto Alegre: Editora da Universidade/UFRGS, 1997.

ROCHE, J. A colonização alemã e o Rio Grande do Sul. Porto Alegre: Globo, 1969. (2 v.)

RODRIGUES, A. S. A Federação dos Trabalhadores na Agricultura Familiar: um novo sindicalismo em construção. 2004. Dissertação (Mestrado Sociologia) - UFPR. Curitiba.

SCHMITT C. J. A CUT dos colonos: história da construção de um novo sindicalismo no campo no Rio Grande do Sul. In: NAVARRO, Z. (Org.). Política, protesto e cidadania no campo. Porto Alegre: Editora da Universidade/UFRGS, 1996.

Tecendo as redes de uma nova agricultura: um estudo socioambiental da região serrana do Rio Grande do Sul. Tese (Doutorado em Sociologia) - UFRGS. Porto Alegre, 2001.

Transição para a agroecologia na Região Sul. In: ENCONTRO NACIONAL DE AGROECOLOGIA. Anais... Rio de Janeiro, 2002.

SEVILLA GUZMÁN, E. Agroecología y desarrollo rural sustentable: una propuesta desde Latino América. XI Curso Intensivo em Agroecologia: Princípios y Técnicas Ecológicas Aplicads a la Agricultura. Rosario, 2000.

TARROW, S. O poder em movimento: movimentos sociais e confronto político. Petrópolis: Vozes, 2009.

THOMPSON, E. P. A miséria da teoria. Rio de Janeiro: Civilização Brasileira, 1981.

\section{Documentos e jornais consultados}

AGRICULTURAALTERNATIVA. CETAP, alternativa popular. Passo Fundo, ano 1, n. 2, 1991.

Constantina: colonos enfrentam a crise. Passo Fundo, ano 2, n. 8, maio/jun. 1992.

COOPAC inaugura posto de recebimento de leite: Romaria da Terra. Passo Fundo, ano 3, n. 10, fev./abr. 1993.

CONTAG. Projeto alternativo de desenvolvimento rural sustentável. Brasília: CONTAG, 1999.

COOPAC/CONAB. Proposta de participação especial com doação simultânea. Constantina, 2006.

CORREIO DO POVO. COOPAC investe no cultivo orgânico. Porto Alegre, ano 105, n. 66, 5 dez. 1999.

CORREIO RIOGRANDENSE. Cooperativa Constantina dobra produção de soja orgânica. Caxias do Sul, ano 93, n. 4.757, nov. 2001.

CUT. Panorama dos ramos da CUT. São Paulo, 2002.

DETR/CUT-RS. II Congresso Estadual: organizando a produção e construindo um novo sindicalismo. Passo Fundo, 1993.

FETRAF-SUL. Documento de Chapecó: Diretrizes básicas para a construção de um projeto de desenvolvimento sustentável e solidário para o fortalecimento da agricultura familiar. Chapecó: V Encontro da Agricultura Familiar [23 a 25 de julho de 2002].

Resoluções do II Congresso da FETRAF-Sul/CUT. Francisco Beltrão, 2007.

. Documento Base do III Congresso da FETRAF-Sul/ CUT: Agricultura familiar: alimento e vida para o Brasil. Erechim, 2010.

JORNAL DE CONSTANTINA. COOPAC incentiva produtos agroecológicos. Constantina, 12 set. 1998.

Recebido em março de 2011.

Aceito em junho de 2011.

Publicado em dezembro de 2011. 